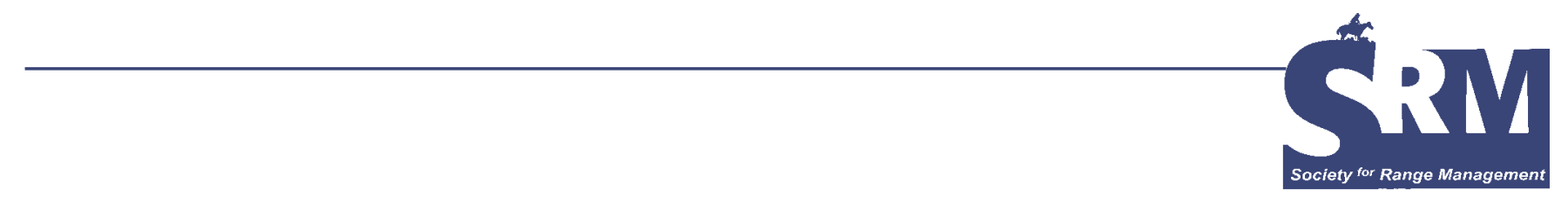

\title{
Trails Merging Along the Rio Grande
}

\section{By Jim Thorpe and Bob Alexander}

$\mathrm{I}$

$\mathrm{n}$ about three months' time, our Society for Range Management will hold its annual gathering in Albuquerque $^{i}$ beside the banks of the Rio Grande, a great river (though often meager in appearance) coursing through the history and ecology of the American Southwest. ${ }^{1}$ Our theme for this meeting is "Merging Trails: Culture, Science, and Innovation." This special issue of Rangelands is intended to set the conference stage and familiarize the reader with some of these trails traversing New Mexico's rangelands, past and present, and to whet an appetite for undertaking an exploration of one's own.

Nearly a half-millennium ago, in April 1540, an ambitious expedition, intent on exploration and conquest, assembled at the Mexican Pacific port of Culiacan, then an outpost of New Spain. ${ }^{2}$ Consisting of over 600 caballeros y soldados (equestrian knights and foot soldiers), and accompanied by hundreds of native allies, servants, and camp followers, its destination was Cibola, a half-rumored northern realm of seven golden cities hoarding the fabulous wealth of yet another (or a "new") Mexico.

The expedition's anxious vanguard, led by its charismatic Captain-General, Francisco Vasquez de Coronado, soon outpaced the main body and its cumbersome supply train (including several hundred soon to be sore-footed sheep, cattle, horses, and pack mules, exotic species destined to have profound influence on North American cultures and ecology). Five months and nearly a thousand miles from his starting point, Coronado, almost exhausted for want of supplies, at last reached Cibola, a land not of golden cities but sedentary villages built with rock or adobe (sun-baked

'(8-12 February 2009; see srmmeetings.org). mud). The shocked inhabitants were members of a somewhat dispersed indigenous culture whose own fortunes had long waxed and waned with inexorable shifts of climate. ${ }^{3}$ The expedition spent the snowy winter of 1540-1541 along the frozen banks of the Rio Grande, just north of present day Albuquerque, not warmed in golden luxury but shivering in requisitioned pueblos, sustained by the tribute of multicolored maize and the forced hospitality of a disgruntled and displaced population.

The following summer these conquistadors ranged eastward across the nearly featureless high plains (as far as today's Dodge City, Kansas), in a vain search for Quivira, another realm of ephemeral riches. They encountered amazing grasslands teeming with vast herds of a peculiar, hairy "cattle" (bison), shadowed by tribes of then-ambulatory

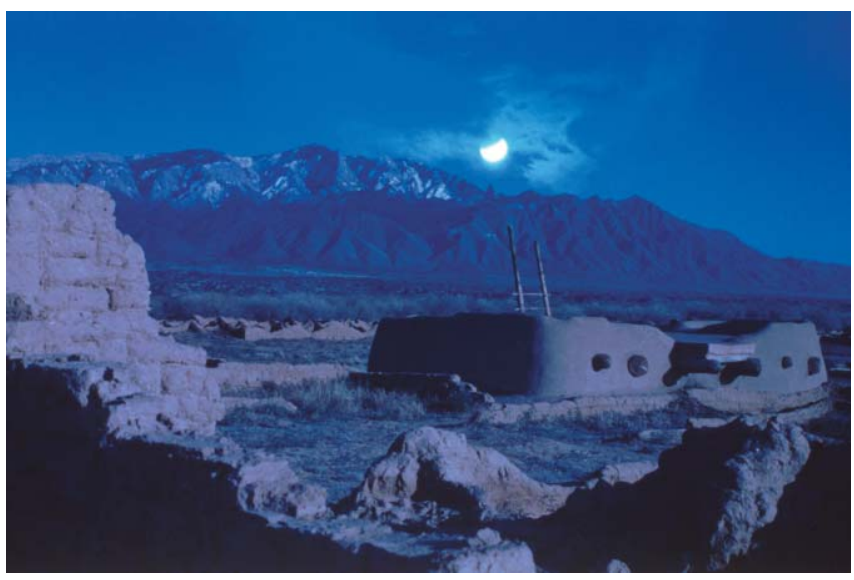

Moonlit ruins of Tiguex (now Coronado State Monument), where the Conquistadors spent a frosty winter. (Courtesy Albuquerque Convention and Visitors Bureau; credit Dick Kent) 
hunters. The expedition turned back, bankrupt and disheartened. It was not until a half-century later that colonists under Don Juan de Oñate returned to the northern Rio Grande in force, introducing an "exotic" regime of Old World cultural norms onto the new. These included Iberian agriculture grafted upon existing native practice, especially the continuance and further development of acequia irrigation (as noted in Karl Wood's article). There was also the permanent introduction of livestock, particularly sheep (see Thad Box's column), which, until the arrival of large-scale cattle ranching following the American Civil War, became the dominant pastoral feature on northern New Mexico rangelands. ${ }^{4}$

For nearly $200 \mathrm{yr}$ this royal "Kingdom of New Mexico" was not as grand as its title, a neglected and relatively impoverished frontier province whose main imperial value was as a buffer to the rumored designs of rival European powers. The colony nonetheless tenuously endured and developed a distinctive regional culture (and piquant cuisine) with a remarkably self-reliant subsistence economy of pastoralism and communal village agriculture. For the most part it remained confined to the life-sustaining Rio Grande and its tributaries, allied with the various Pueblos but experiencing alternating periods of bitter conflict and uneasy coexistence with the peripheral native nations, now empowered and emboldened by their acquisition and mastery of the horse. ${ }^{\text {ii }}$

As the tide of the Spanish empire subsided, that of the upstart American republic rose, and new trails of exploration, followed by those of commerce and conquest, soon traced across this diverse landscape. Following his 1806 arrest by Spanish authorities for unintentional trespass, US Lt Zebulon Pike was escorted through the province as an unwilling guest (and an effective spy) for 6 mo until he was released near New Orleans. His intriguing journal observations, ${ }^{5}$ published following his return, provided inspiration for further gringo incursion. In 1821, as Mexico finally succeeded in its lengthy struggle for independence, intrepid Missouri merchants reached Santa Fe, intent on the lucrative trade of coveted Yankee textiles and manufactured goods for Mexican mules and coveted Chihuahuan silver.

Clear profits of $100 \%$ or more were the motivation for undertaking the 2-mo-plus journey across nearly a thousand miles from the "prairie ports" of Missouri. ${ }^{6}$ While recounting hazards and hardships, travelers' journals offer tantalizing hints of contemporary range ecology, but their paramount concerns were the daily procurement of forage and water, favorable weather, and the intentions of the native tribes whose resources the caravans increasingly exploited. ${ }^{7}$

Commerce soon led to conquest when, in the opening phases of the war between the United States and Mexico,

\footnotetext{
ii And, for the Navaho, churro rams and ewes.
}

General Stephen Watts Kearney descended the trail in 1846 to take possession of the New Mexico territory and "march" on to California.iii Within decades Coronado's "hairy cattle" were nearly exterminated, and the free-ranging tribes, defeated, were confined to reservations. ${ }^{8}$ Thousands of "beeves" were trailed into the territory by pioneer cattlemen like Charles Goodnight ${ }^{9}$ to provision army outposts, mining camps, and new settlements, along with seedstock for the new ranching enterprises rapidly staking claim to the "free grass" of the "open range." The arrival of railroads in the 1880s ended the era of the Santa Fe Trail while accelerating immigration and development. The export of commodity timber, minerals, livestock, and (limited) dry land harvests were facilitated, as was also the importation of transforming technologies like windmills, barbed wire, and the homesteader's sod-busting plow. The next half-century saw rangeland cycles of economic and ecological boom and bust, drought ${ }^{\text {iv }}$ and deluge, ${ }^{v}$ overgrazing ${ }^{\text {vi }}$ and overplowing in many areas that culminated dramatically in the great drought and depression of the 1930s Dust Bowl. ${ }^{10}$

Not all trails were of commerce or conquest; there were also those of knowledge and inquiry. Military explorers such as Zebulon Pike were instructed as cartographers and field naturalists and were charged with obtaining useful scientific information (albeit with an eye toward future potential "management"). Kelley Allred's article notes the many naturalists who trailed across the region since the 1800s, especially the story of New Mexico's foremost pioneering botanist, E.O. Wooton, the first to describe and categorize in detail the seven major ecoregions of New Mexico and their ecological attributes. Rex Pieper relates how these early efforts were formalized with the development of academic and research institutions (including the "living Long-Term Ecological Research laboratories" of the Jornada Basin and Sevillita) and the gradual emergence of the multifaceted, interdisciplinary art and science of Range Management.

New Mexico has long attracted artists, writers, and personalities like Georgia O'Keefe and Willa Cather, inspiring some of their most enduring work. It has been likewise on the range. Pioneering managers include Aldo Leopold, who arrived in New Mexico a hundred years ago ${ }^{\text {vii }}$ to begin his remarkable career in wildlife/habitat management. His extensive field experience was critical to his development as an influential conservationist-philosopher leading to the creation of the first national wilderness. Allan Savory, who established Holistic Management International in Albuquerque in 1984, has had a significant influence on

\footnotetext{
iii A harrowing journey, as described by Stiles.

iv See poetry page this issue for experience of the 1950s drought.

$\checkmark$ (i.e., periods of above average rainfall - ed.)

vi See Havstad's discussion of Wooten's 1908 "The Range Problem in New Mexico" in the June issue of this journal.

vii This 2009 centennial will be commemorated with a number of special events.
} 
rangeland paradigms and practice worldwide. ${ }^{\text {viii }}$ Mediamogul Ted Turner has blended commerce, conservation, and science (and notably, native bison herbivory) in what is effectively a very large-scale experiment in multilandscape management. ${ }^{\text {ix }}$

While New Mexico may be blessed with considerable human talent and ecological diversity, its matrix of land tenure and modes of management may seem maddeningly complex. The state map ${ }^{\mathrm{x}}$ is a multicolored "checker-board" of various federal (Forest Service, Bureau of Land Management [BLM], military, national parks), state, tribal, and private lands. Many ranching operations, large and small, are overlain among some of these jurisdictions, and integrating landscape scale management across such boundaries can be challenging, especially in areas fragmented by encroaching urbanization or disturbed by energy development. There are some notable successes in collaborative management, however, such as BLM's Restore New Mexico initiative, and the Canadian River Riparian Restoration Project, a comprehensive, watershed-wide saltcedar control project. ${ }^{\mathrm{xi}}$

Invasive plant species ${ }^{\mathrm{xii}}$ concerns include various thistles and knapweeds, riparian invaders (saltcedar and Russian olive), and the regional encroachment of native juniper, sagebrush, mesquite, and creosote onto former grasslands. Management of some wildlife species, especially expanding elk herds and those of introduced oryx pose some challenges, as well as, in some areas, feral horses, and, surprisingly, feral hogs. Threatened and endangered species much on the rangeland radar include lesser prairie chickens, the Southwest willow flycatcher, the Rio Grande silvery minnow, the Mexican jaguar, and the Mexican wolf.

The lobo (wolf), especially, has been a high-profile rallying point for different societal segments with conflicting views and perspectives on the role of rangelands, ranging from the release zone ranch communities that directly experience impacts ${ }^{\text {xiii }}$ from the introduced predators to the organizations dedicated to their comprehensive re-establishment in Southwestern ecosystems. Some of the latter are among the most vocal and determined critics of livestock grazing and have proven quite adept in using the regulatory process (and the lawsuit) to promote their objectives. . $^{\text {xiv }}$

But not all is contention and conflict. As Kris Havstad notes, there are recent instances of innovative management approaches (he calls them acts of "creative desperation").

\footnotetext{
viii First noted in a 1969 Journal of Range Management article by New Mexico rancher Sid Goodloe.

ix See www.tedturner.com/enterprises/ranches.asp.

× See http://www.nm.nrcs.usda.gov/technical/fotg/section-1/maps. html.

xi See www.blm.gov/nm/st/en/prog/restore_new_mexico and www. hardingcounty.org/Ag-NatResources/CRRRP/CRRRProject.htm.

xii For comprehensive listings http://weeds.nmsu.edu/.

xiii See wolfcrossings.org.

xiv For example, see www.wildearthguardians.org.
}

These include the collaborative cross-boundary stewardship of the Malpais Borderlands Group, the experiment in multiple-use, sustainable self-management at the Valles Caldera National Preserve, and the encouraging partnership of pragmatic environmentalists and ranchers seeking common ground through the Quivira Coalition. ${ }^{\mathrm{xv}}$ Rangeland innovation is also alive and well, benefiting from the contributions of cutting edge rangeland research, an active cadre of Natural Resources Conservation Service rangeland specialists, New Mexico State University extension service agents, and the interdisciplinary New Mexico Range Improvement Task Force, ${ }^{\text {vii }}$ as well as the increasing societal recognition of the "ecological services" "xvi that well-managed rangelands can provide worldwide. Yet, as special guest contributor Bill DeBuys notes in his intriguing essay on our perceptions of ecological change, future climate challenges ${ }^{\text {xviii }}$ may very well demand the greatest resilience from our culture, the greatest diligence from our science, and our greatest capacity for "creative desperation" in innovative response.

It's been but a millisecond of geological time, and perhaps just a lingering blink of an eyelid in the passage of human

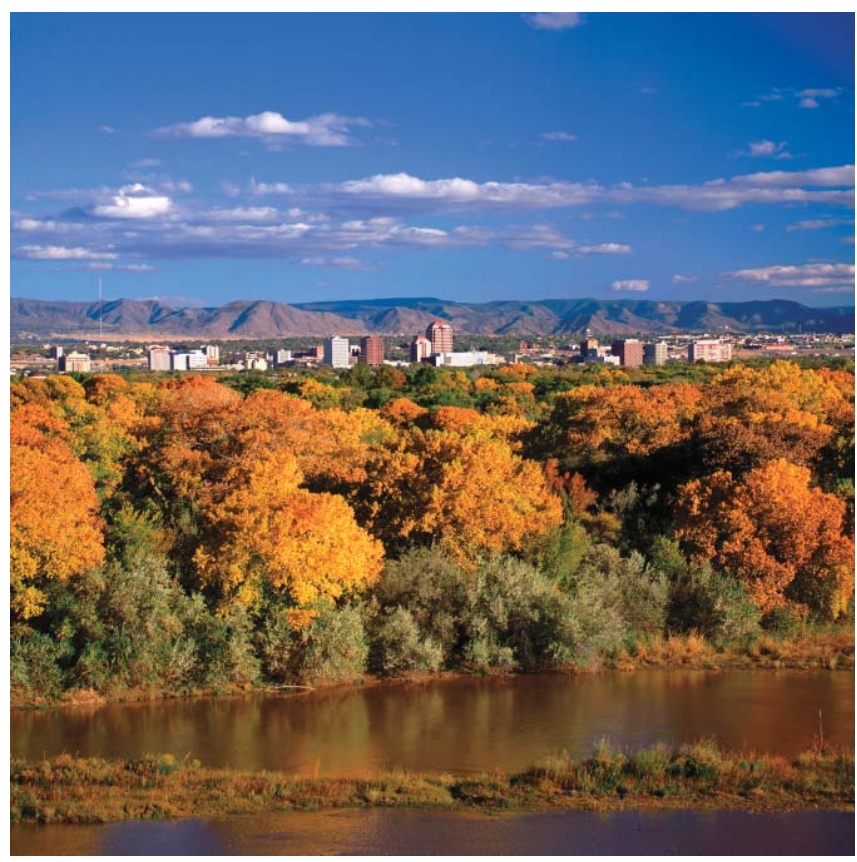

Albuquerque, once a sleepy agricultural settlement, spreads from the Sandia Mountains to the Rio Grande bosque, a riparian zone thick with both native and exotic vegetation. (Courtesy Albuquerque Convention and Visitors Bureau; credit www.MarbleStreetStudio.com)

xv See book review this issue.

xvi See http://cahe.nmsu.edu/ritf/.

xvii These include not only traditional "food and fiber" but also the maintenance of watersheds, habitats, biodiversity, open space, and soil carbon sequestration.

xviii For detailed discussions of climate challenges on rangelands worldwide see the June issue of this journal. 
history (and the first stirrings of "management"), since Coronado first made his entrada and wintered on the frosty banks of the Rio Grande. As you travel to Albuquerque for "SRM LXII," the 62nd annual meeting of our Society for Range Management, by land or air, you'll most likely be traversing trails of those who have gone before. As you arrive, you may note the thick brown band of the Rio Grande, groved with native cottonwoods (and invasive saltcedars), intermittently watering remnant fields of alfalfa, languidly sweeping alongside a modern metro of a near half-million. At night, from a little distance, it glitters golden.

\section{References}

1. Horgan, P. 1954. Great river: the Rio Grande in North American history. New York, NY, USA: Holt, Rinehart and Winston. 1020 p.

2. Bolton, H. E. 1949. Coronado: knight of pueblos and plains. New York, NY, USA: Whittlesey; Albuquerque, NM, USA: University of New Mexico Press. 491 p.

3. Blinman, E. Cultural adaptation to 2000 years of climate change in the Southwest. Quivira Coalition conference presentation; January 2008; Albuquerque, NM, USA. Available at: http://quiviracoalition.org/Detailed/Annual_Conference/ Archives/Seventh_An...rence/Cultural_Adaptation. Accessed 7 August 2008.
4. JordAn, T. 1993. North American cattle-ranching frontiers: origins, diffusion, and differentiation. Albuquerque, NM, USA: University of New Mexico Press. 439 p.

5. Pike, Z. 1932. The southwestern journals of Zebulon Pike, 1806-1807. 2006, revision. Albuquerque, NM, USA: University of New Mexico Press. 286 p.

6. Hyslop, S. 2002. Bound for Santa Fe: the road to New Mexico and the American conquest 1806-1848. Norman, OK, USA: University of Oklahoma Press. 514 p.

7. Gregg, J. 1844. Commerce of the prairies. 1926, reprint. Chicago, IL, USA: Lakeside Press. 343 p.

8. Stiles, H. 2006. Blood and thunder: the epic story of Kit Carson and the conquest of the American West. New York, NY, USA: Doubleday. 578 p.

9. Hagan, W. T. 2007. Charles Goodnight, father of the Texas panhandle. Norman, OK, USA: University of Oklahoma Press. $147 \mathrm{p}$.

10. Egan, T. 2006. The worst hard time: the untold story of those who survived the Great American Dust Bowl. Boston, MA, USA: Mariner Books, Houghton Mifflin Company. 340 p.

Authors are Rancher, JT Land E Cattle, jtlandandcattle.com, Newkirk, NM 88431, USA, jimthorpe@wildblue.net (Thorpe); and Certified Professional in Range Management, Co-chair 2009 SRM Annual Meeting, PO Box 23507, Santa Fe, NM 87502, USA (Alexander). 